\title{
Seed priming for alleviation of heavy metal toxicity in plants: An overview
}

\author{
Rajkumar Prajapati, Sunita Kataria \& Meeta Jain* \\ School of Biochemistry, Devi Ahilya Vishwavidyalaya, Khandwa Road, Indore 452 001, Madhya Pradesh, India \\ *Email:mijainmeeta@gmail.com
}

\section{ARTICLE HISTORY}

Received: 13 February 2020

Accepted: 16 April 2020

Published: 01 July 2020

\section{KEYWORDS}

abiotic stress

magnetopriming

nano-priming

seed germination

vigor

\begin{abstract}
Heavy metal (HM) toxicity is vital environmental constraint that limits crop productivity worldwide. Several physiological processes necessary for plant survival have been found to be affected by HM toxicity. In recent farming, advanced mechanisms are being developed to overcome from the stresses to enhance the yield. The seed priming is an affordable method for plants to survive under abiotic and biotic stresses. Priming is useful for commercial seed lots by seed technologists to increase the vigor of the seeds in terms of germination potential and enhance the tolerance against various stresses. It also removes the pollution threats by minimizing the uses of chemical fertilizers. The seeds having deprived of quality in terms of seed germination and seedling characters ultimately affect the growth, photosynthetic performance and yield of the plants under HM stress. On the other hand seed primed with various seed priming methods such as hydropriming, hormonal priming, chemical priming, biopriming, magnetopriming and nanopriming perform well under HM toxicity. Seed priming methods have been considered as a unique approach to get rid of HM stress by enhancing the seed germination, seedling vigor, rate of photosynthesis, biomass accumulation and thus increase the crop productivity. The present review provides an overview of different seed-priming methods and their role in alleviation of adverse effects of HM stress in plants.
\end{abstract}

\section{Introduction}

Plants live in a dynamic environment where many adverse conditions in the form of abiotic stresses such as cold, drought, salinity, heavy metal (HM) toxicity and UV-B stress are generated which affect their growth and development (1). Among various stress factors, heavy metal toxicity is considered a potential environmental enemy in natural and agriculture ecosystems. The increase in industrialization has escalated heavy metal pollution resulting in environmental, agricultural and human health problems $(2,3)$. Though HMs are naturally present in the soil; anthropogenic and geologic activities further increase their concentration, thus they cause harmful effects on organisms $(3,4)$. Toxic metal contaminated soil and water poses a severe risks to public and food safety $(3,4)$. Among these heavy metals, nickel (Ni), manganese (Mn) and zinc ( $\mathrm{Zn})$ are considered as essential metals which are required in small amount and play a significant role in numerous physiological processes of plants $(5,6)$. Nonessential metals such as cadmium (Cd), mercury $(\mathrm{Hg})$ and lead $(\mathrm{Pb})$ do not have important biological role. Instead, these metals when accumulate in higher concentrations disturb the physiological, structural and biological functions $(2,6)$. The general detrimental effects of HMs are chlorosis, distorted nutrient assimilation, reduction in growth and photosynthesis; lower biomass accumulation and senescence, which eventually can cause the death of the plants (7-9). In the current scenario, it is quite a challenge to overcome/repair the damage brought by HMs stress in plants.

Heavy metals are now considered as the second most pollutants, including pesticides, $\mathrm{CO}_{2}$ and $\mathrm{SO}_{2}$, as they are most hazardous pollutant which probably may beat solid and atomic waste (8). Natural activities like volcano eruption and rocks erosion have contributes in rising the release of toxic elements to the atmosphere; though, increased human activities such as mining, refining and painting have enhanced

(C) Prajapati et al (2020). This is an open-access article distributed under the terms of the Creative Commons Attribution License, which permits unrestricted use, distribution and reproduction in any medium, provided the original author and source are credited (https://creativecommons.org/licenses/by/4.0/).

To cite this article: Prajapati R, Kataria S, Jain M. Seed priming for alleviation of heavy metal toxicity in plants: An overview. Plant Science Today. 2020; 7(3):308-313. https://doi.org/10.14719/pst.2020.7.3.751 
their concentration in the biosphere $(10,11)$. Around $70 \%$ of the heavy metals and their compounds reach to our body and food is considered as the main route $(10,11)$. The interruption of nature's geochemical cycle of metals by human results in addition to one or more of heavy metals in the soil and water which is dangerous to human health, plants and animals (1214). At the cellular level, toxic effect of HMs is mediated by producing reactive oxygen species (ROS) and causing oxidative stress. Activation of various antioxidative defence mechanisms and reduction in the uptake of heavy metal are the defense mechanisms used by the plants to sustain their growth and productivity under HM toxicity (11). General effects of heavy metal stress on the plants are illustrated in Fig. 1.

During past few years various seed priming methods have been developed to overcome the toxic and consistent appearance of the seedlings which results in high vigor and better yield $(8,16,18)$.

Priming of seeds can be performed in different ways such as 1. Hydropriming, 2. hormonal priming, 3. chemical priming, 4. biopriming, 5. magnetopriming and 6. nanopriming (8, 16, 18-22). Primed seeds exhibit changes in their physiological and biochemical mechanisms with beneficial effects on germination and early seedling characteristics along with stimulation of the activity of antioxidant enzymes that scavenge the reactive oxygen species (ROS) relative to unprimed seeds under stress as well as under non-stress conditions $(23,24)$.

\section{Hydro-priming}

It involves the soaking of seeds in distilled water before sowing (25). It is quite a simple, cost-effective

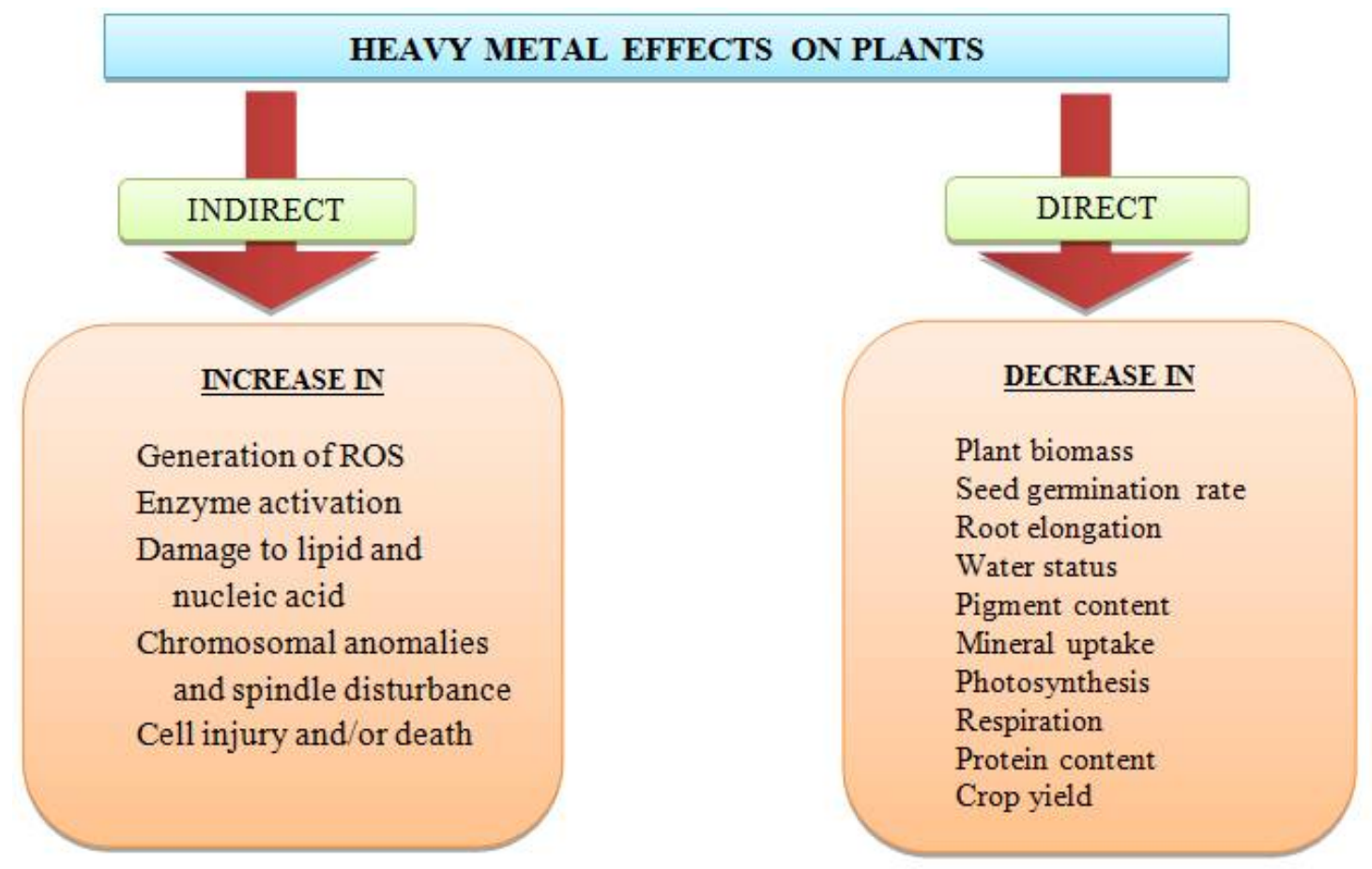

Fig. 1. Direct and indirect toxic effects of Heavy metals on plants (8-11).

and adverse effects of HM on crop plants and agricultural systems, to fulfil the global food demand. In this review seed priming is discussed in the context of their potential for alleviation of metal stress.

\section{Seed priming methods}

Seed priming is a pre-sowing treatment that offers the possibility to improve post-harvest seed quality and allows the break of dormancy leading to the increase germination rate, speed and uniformity. The seed priming involves the initiation of germination metabolism by controlling the hydration of seeds and activating various metabolic processes before radical protrusion $(15,16)$. Some natural and synthetic compounds which are used to prime the seeds before germination, induce biological alteration in plants (8, 17). Further, seed priming methods have become a promising approach in protecting plants from biotic and abiotic stresses $(8,17)$ by quicker germination and a harmless priming method which is preferred for increased osmotic adjustment ability of the seeds, seedling establishment and crop yield under non stress as well as stress conditions (26). Karalija and Selović (27) found an improvement in photosynthetic activity and carbohydrate metabolism in hydroprimed maize seeds grown under $\mathrm{Cd}$ stress. Kumar and Boss (28) also suggested that hydroprimed seeds may conquer the phytotoxic effects of the HM stress in the germinating seeds of rice due to increase in a-amylase activity. It has also been suggested that the inhibitory effect of mercuric chloride $\left(\mathrm{HgCl}_{2}\right)$ on seed germination and seedling growth of wheat can be alleviated by hydropriming (21).

\section{Hormonal-priming}

In this kind of priming seeds are pre-treated with different hormones such as auxins, cytokinins, gibberellins, salicylate etc. which stimulate the seedling's growth and development $(8,28-30)$. In 
agronomical crop management practices, phytohormones as regulator of heavy metal absorption have been used to alleviate the HM toxicity $(8,30)$. It was found that seed germination in Cd contaminated areas can be efficiently improved using hormonal priming with auxin, cytokinin, gibberellin, abscisic acid and ethylene in pigeon pea (Cajanus Cajan) (31). It was reported that Salicylic acid (SA) and 24-epibrassinolide increase the relative water content and HM tolerance index in Brassica juncea (32). Further, pre-treatment of seeds with the combination of 24-epibrassinolide and SA, lessen the adverse effects of $\mathrm{Pb}$ stress through alteration in antioxidative defense response and enhanced osmolyte contents in B. juncea (33). It was reported that SA and sodium hydrosulfide (NaHS) pretreatments decrease the adverse effects of $\mathrm{Pb}$ stress in Zea mays plants through increase in glycine betaine (GB) and nitric oxide (NO) contents and by regulation of genes participating in methionine metabolism (34). Under Cr stress, seed priming with SA improved the morphological, physiological, biochemical and metabolic parameters of rice (35). Osmopriming with polyethylene glycol (PEG) and hormo-priming with gibberellic acid (GA) improved germination and early seedling growth of white clover in a heavy metal-contaminated soil (36).

\section{Chemical priming}

In this kind of priming, seeds are pre-treated with various chemicals such as selenium (Se), Silicon (Si), paclobutrazol, calcium chloride, potassium phosphate, chitosan, putrescine, butenolide, nitric oxide, hydrogen peroxide, hydrogen sulfide, melatonin, defensins and polyamines to improve germination rate and enhance abiotic stress tolerance (37-41). Defensins are specifically reported to increase $\mathrm{Zn}$ tolerance at higher concentrations (50 and $100 \mathrm{mM}$ ) in wheat germinated grains through alleviating the oxidative stress by up regulation of the antioxidant enzymes (42). This could be unexpected role for defensins which opens up new horizons for the investigation of defensin mechanisms of action (42). Melatonin has been found to ameliorate copper toxicity through improvement in copper sequestration, activating the ROS scavenging, changing the gene expressions, increasing the levels of glutathione and phytochelatin and further improved the distribution of nutrient elements which were disturbed by $\mathrm{Cu}^{2+}$ (43). Cadmium induced inhibition of growth, chlorophyll contents, gasexchange attributes and photosynthetic efficiency in Vicia faba has been reported to be alleviated by calcium chloride (44). The significant reduction in boron toxicity by reducing the oxidative damage and increased activities of antioxidative enzymes has been shown by calcium (45). Pre-soaking of seeds with Se (5, 10 and $20 \mu \mathrm{M})$ alleviated the negative effect of cadmium (Cd) on growth and due to a decrease in oxidative injuries caused by Cd (46).

Silicon (Si) has been reported to alleviate the toxicity of various heavy metals in crops plants (47, 48) through an increase in the $\mathrm{pH}$ of the growth media (49), stimulation of the antioxidant enzymes $(50,51)$ and reduction of metal uptake $(48,52)$. Further, it was reported that Si lessens the Cd toxicity in wheat seedlings by increasing the plant growth and antioxidant capacity by reducing the uptake of $\mathrm{Cd}$ and lipid peroxidation (52).

\section{Biological priming or bio-priming}

It consists of coating the seeds with a bacterial biocontrol agent such as Pseudomonas aureofaciens Kluyver AB254 and after that the seeds were hydrated for $20 \mathrm{hrs}$ under warm conditions $\left(23^{\circ} \mathrm{C}\right)$ in a self-sealing plastic bag in moist vermiculite or on moist germination blotters and before radicle emergence the seeds were removed (53). Applying beneficial microorganisms to the seeds during priming may further improve the development of the crop and it may help the plant to be healthy for long duration (54). It was reported that application of plant-microbe synergy to restore lands, contaminated with HMs is a promising technique (55). It has been suggested the benefits of heavy metal tolerant-plant growth promoting (HMT-PGP) bacterial strains (PGPB) such as Alcaligenes faecalis MG257493.1, Bacillus cereus MG257494.1 and $A$. faecalis MG966440.1); as they perform various functions like increased plant growth and removal or detoxification of HM from the soil (56). Further, these three HMT-PGPB strains were employed for alleviation of the toxic effects of heavy metal's on Sorghum bicolor and increased its growth characteristics (57).

\section{Magnetopriming (MP)}

MP involves treatment of seeds using a magnetic field before sowing. There is a great impact of such physical treatment on multiple levels from morphostructural aspects to changes in gene expression (22). Magnetopriming with static magnetic field (SMF) enhance the speed of germination, plant height, leaf area, photosynthetic pigment, efficiency of PS II, rate of photosynthesis and yield of soybean plants under salt and UV-B stress $(20,22)$. It was observed that MP mitigates the adverse effect of cadmium stress by reducing the level of malondialdehyde, $\mathrm{H}_{2} \mathrm{O}_{2}$ and $\mathrm{O}_{2-}$ and increased the growth and photosynthetic parameters, NO content and nitric oxide synthase activity (58). It has been reported that the mechanism of alleviation of adverse effects of salt and HMs stress by MP is related to NO signaling $(22,58)$. It was found that metallothionein and receptor for activated $\mathrm{C}$ kinase 1 (RACK1) play a critical role in the ROS mediated signal transduction pathway to enhance the seed germination and seedling vigor in magnetoprimed tomato seeds (59).

\section{Nanopriming}

It includes the use of several metal nanoparticles (NPs), such as AuNPs, AgNPs, FeNPs, CuNPs, ZnNPs, ZnONPs and $\mathrm{TiO}_{2}$ NPs etc. Nanoparticles based on carbon (e.g., fullerene and carbon nanotubes) are also useful as seed priming agents for promoting growth characteristics and improve the stress tolerance in crop plants. Nano-TiO ${ }_{2}$ alleviates the $\mathrm{Cd}$ toxicity in the plants by increase in the growth and photosynthesis of plants (60). Nano-scale hydroxyapatite can alleviate the $\mathrm{Cd}$ toxicity in Brassica juncea (61). It was also found that Si NPs protect maize seedlings against arsenic (As) toxicity through enhancing the activities of antioxidant 
enzymes like ascorbic acid peroxidase (APX), dehydro ascorbate reductase (DHAR), superoxide dismutase (SOD), glutathione reductase (GR) and limiting the accumulation of As and ROS (62). Nano-priming with AgNPs enhanced the a-amylase activity, resulting in higher soluble sugar content for supporting seedling growth. Furthermore, these NPs stimulate the upregulation of aquaporin genes in germinating seeds (63). It was found that seed priming with Si NPs positively increase the growth, biomass and yield of wheat plants under cadmium contaminated soil (18).

\section{Conclusion}

These methods of seed-priming are the best way to grow the crops under unfavorable conditions and overcome the germination related problems, reduce germination time, improve crop yield and when crops are grown in HM contaminated areas. Significant amount of work has been carried out on the importance of seed-priming techniques for different crop plants affected by the heavy metal stress. The data presented in this mini review can be useful for developing agro-ecological technology based on the exogenous application of seed priming agents to improve tolerance under HM contamination which may contribute to the agricultural or ecological sectors, and explore ways for further improvisation. This low input technique is sustainable and will help in reclamation of $\mathrm{HMs}$ contaminated soils, thus increasing the quality of seeds and crop yield in such areas.

\section{Acknowledgements}

The authors are thankful to the CSIR New Delhi for JRF (09/301(0140) 2019-EMR-I) to RP for providing financial support.

\section{Authors' contributions}

SK and MJ drafted the outline of review; writing original draft preparation by RP and SK; writingreview and editing and revision by SK and MJ.

\section{Conflict of interest}

No potential conflict of interest was reported by the authors.

\section{References}

1. Zhu JK. Abiotic stress signaling and responses in plants. Cell 2016;167(2):313-24. https://doi:10.1016/j.cell.2016.08.029

2. Fahad S, Chen Y, Saud S, Wang K, Xiong D, Chen C, et al. Ultraviolet radiation effect on photosynthetic pigments, biochemical attributes, antioxidant enzyme activity and hormonal contents of wheat. J Food Agric Environ. 2013;11: 1635-41. http://dx.doi.org/10.5772/intechopen.75806

3. Anjum SA, Tanveer M, Hussain S, Bao M, Wang L, Khan I, et al. Cadmium toxicity in Maize (Zea mays L.): consequences on antioxidative systems, reactive oxygen species and cadmium accumulation. Environ Sci Pollut Res. 2015;22:17022-30.
4. Chibuike GU, Obiora SC. Heavy metal polluted soils: Effect on plants and bioremediation methods. Appl Environ Soil Sci. 2014;Article ID 752708. https://doi.org/10.1155/2014/752708

5. Hafiz FB, Zahida Z, Fahad S, Sunaina A, Hafiz MH, Ahmad NS et al. Arsenic uptake, accumulation and toxicity in rice plants: possible remedies for its detoxification: a review. Environ Sci Pollut Res. 2017;24:9142-58. https://doi.org/10.1007/s11356-0178462-2

6. Shahzad B, Tanveer M, Che Z, Rehman A, Cheema SA, Sharma $\mathrm{A}$, et al. Role of 24- epibrassinolide (EBL) in mediating heavy metal and pesticide induced oxidative stress in plants: a review. Exotoxicol Environ Saf. 2018;147:935-44. https://doi.org/ 10.1016/j.ecoenv.2017.09.066

7. Ali S, Bai P, Zeng F, Cai S, Shamsi IH, Qiu B, Wu F, Zhang G. The ecotoxicological and interactive effects of chromium and aluminum on growth, oxidative damage and antioxidant enzymes on two barley genotypes differing in $\mathrm{Al}$ tolerance. Environ Exp Bot. 2011;70:185-91. https://doi.org/10.1016/ j.envexpbot.2010.09.002

8. Sytar O, Kumari P, Yadav S, Brestic M, Rastogi A. Phytohormone priming: regulator for heavy metal stress in plants. J Plant Growth Reg. 2019;38:739-52. https://doi.org/10.1007/ s00344018-9886-8

9. Sharma A, Kapoor D, Wang J, Shahzad B, Kumar V, Bali AS, Jas rotia S, Zheng B, Yuan H, Yan D. Chromium bioaccumulation and its impacts on plants: An overview. Plants. 2020;9:100. https://doi.org/10.3390/plants9010100

10. Sharma A, Singh GP, Fabrizio A, Bali AS, Shahzad B, Tripathi DK, Brestic M, Skalicky M, Landi M. The role of salicylic acid in plants exposed to heavy metals. Molecules. 2020;25:540. https://doi.org/10.3390/molecules25030540

11. Shahid M , Khalid S, Abbas G, Shahid N, Nadeem M, Sabir M Aslam M, Dumat C. Heavy metal stress and crop productivity. In: K.R. Hakeem (ed.), Crop Production and Global Environmental Issues. Springer International Publishing Switzerland 2015; pp. 1-25. https://10.1007/978-3-319-23,162-4_1

12. Tchounwou PB, Yedjou CG, Patlolla AK, Sutton DJ. HM toxicity and the environment. 2012;101:133-64. https://doi.org/ 10.1007/978-3-7643-8340-4-6

13. Singh R, Gautam N, Mishra A, Gupta R. Heavy metals and living systems: An overview. Indian J Pharmacol. 2011;43(3):24653. https://doi:10.4103/0253-7613.81505

14. Dixit R, Wasiullah Malaviya D, Pandiyan K, Singh UB, Sahu A, et al. Bioremediation of heavy metals from soil and aquatic environment: an overview of principles and criteria of fundamental processes. Sustainability. 2015;7:2189. https://doi.org/ $10.3390 /$ su 7022189

15. Hulten M, Pelser M, van Loon LC, Pieterse CMJ, Ton J. Costs and benefits of priming for defense in Arabidopsis. Proc Natl Acad Sci USA. 2006;103:5602-07. https://doi.org/10.1073/ pnas.0510213103

16. Jisha KC, Vijaykumari K and Puthur JT. Seed priming for abiotic stress tolerance: an overview. Acta Physiol Plant. 2013;35:1381-96. https://doi.org/rdcu.be/bFzuE

17. Goswami AP. Seed Priming: a technique to improve seed performance. International J Chemical Stud. 2019;7(3):966-71.

18. Hussain A, Rizwan M, Ali Q, Ali S. Seed priming with silicon nanoparticles improved the biomass and yield while reduced the oxidative stress and cadmium concentration in whea grains. Environmental Science and Pollution Research. 2019;26:7579-88. https://doi.org/10.1007/s11356-019-04210-5

19. Ullah A, Shahzad B, Tanveer M, Nadeem F, Sharma A, Lee DJ et al. Abiotic stress tolerance in plants through pre-sowing seed treatments with mineral elements and growth regulators. In Priming and pretreatment of seeds and seedlings, M. Hasanuz zaman, V Fotopoulos (eds.), Springer Nature Singapore Pvt. Ltd. pp. 427-45. https://doi.org/10.1007/978-981-13-8625-1_21

20. Kataria S, Jain M. Magnetopriming alleviates adverse effects of abiotic stresses on plants. In: Plant tolerance to environmental stress: Role of phytoprotectants. 1st Edition. Mirza Hasanuzzaman, Masayuki Fujita, Hirosuke Oku, Tofazzal Islam M. (Eds.), CRC Press, 2018; Chapter-26, pp. 427-38. DOI https://doi.org/ $10.1201 / 9780203705315$ 
21. Kumar M, Pant B, Mondal S, Bose B. Hydro and halo priming: influenced germination responses in wheat Var-HUW-468 under heavy metal stress. Acta Physiol Plant. 2016;38:217. https:// doi.org/10.1007/s11738-016-2226-3)

22. Kataria S, Tripathi DK, Jain M, Singh VP. Role of Nitric oxide during germination in regulation of magneto-priming induced alleviation of salt stress in Soybean (Glycine max). Physiologia Plant. 2020;168:422-36. https://doi.org/10.1111/ppl.13031

23. Ahmad P, Nabiand G, Ashraf M. Cadmium-induced oxidative damage in mustard (Brassica Juncea (L.) Czern. \& Coss.) plant can be alleviated by salicylic acid. South Afr J Bot. 2011;77:3644. https://doi.org/10.1016/j.sajb.2010.05.003

24. Younesi O, Moradi A, Effect of different priming methods on germination and seedling establishment of two medicinal plants under salt stress conditions. Cercetări Agronomice în Moldova 2015; Vol. 48, No. 3 (163). https://doi.org/10.1515/ cerce-2015-0040

25. Pill WG, Necker AD. The effects of seed treatments on germination and establishment of Kentucky bluegrass (Poa pratense L.). Seed Sci Technol. 2001;29:65-72.

26. Kaur S, Gupta AK, Kaur N. Effect of osmo-and hydro-priming of chickpea seeds on seedling growth and carbohydrate metabolism under water deficit stress. Plant Growth Regul. 2002;37:17-22. https://doi.org/10.1023/A: 1020310008830.

27. Karalija E, Selović A. The effect of hydro and proline seed priming on growth, proline and sugar content, and antioxidant activity of maize under cadmium stress. Environmental Science and Pollution Res. 2018; 25:33370-80. https://doi.org/ 10.1007/s11356-018-3220-7

28. Kumar N, Boss B. Hydro, $\mathrm{Mg}\left(\mathrm{NO}_{3}\right)_{2}$ and kinetin primed seeds mitigate the inhibitory effects of $\mathrm{CdCl}_{2}$ in germinating rice. J Pharmacognosy Phytochem. 2018;7(5):2578-84.

29. Lee SS, Kim J H, Hong S B, Yuu S H, Park E H. Priming effect of rice seeds on seedling establishment under adverse soil conditions. KJ Crop Sci. 1998;43:194-98.

30. Piotrowska-Niczyporuk A, Bajguz A, Zambrzycka E, Godlewska Żyłkiewicz B. Phytohormones as regulators of HM biosorption and toxicity in green alga Chlorella vulgaris (Chlorophyceae). Plant Physiol Biochem. 2012;52:52-65. https://doi.org/10.1016/ j.plaphy.2011.11.009

31. Sneideris LC, Gavassi MA, Campos ML, D’Amico-Damião V, Carvalho RF . Effects of hormonal priming on seed germination of pigeon pea under cadmium stress. An Acad Bras Cienc. 2015;87(3):1847-52. https://doi.org/10.1590/00013765201520140332

32. Kohli SK, Handa N, Sharma A, Gautam V, Arora S, Bhardwaj R, Wijaya L, Alyemeni MN, Ahmad P. Interaction of 24-epibrassinolide and salicylic acid regulates pigment contents, anti-oxidative defense responses, and gene expression in Brassica juncea L. seedlings under $\mathrm{Pb}$ stress. Environ Sci Pollut Res. 2018;25:15159-73. https://doi.org/10.1007/s11356-018-1742-7

33. Kohli S, Handa N, Bali S, Arora S, Sharma A, Kaur R, Bhardwaj R. Modulation of antioxidative defense expression and os molyte content by coapplication of 24-epibrassinolide and salicylic acid in $\mathrm{Pb}$ exposed Indian mustard plants. Ecotoxicology Environmental Saf. 2018;147:382-93. https://doi.org/10.1016/j.ecoenv.2017.08.051

34. Zanganeh R, Jamei R, Rahmani F. Impacts of seed priming with salicylic acid and sodium hydrosulfide on possible metabolic pathway of two amino acids in maize plant under lead stress. Mol Biol Res Commun. 2018;7(2):83-88. https://doi.org/ 10.22099/mbrc.2018.29089.1317

35. Shinwari KI, Jan M, Shah G, Khattak SR, Urehman S, Daud MK, Jamil M. Seed priming with salicylic acid induces tolerance against chromium (VI) toxicity in rice (Oryza sativa L.). Pakistan J Bot. 2015;47:161-70.

36. Galhaut L, Lespinay A,- Walker D, Bernal, M., Correal, Enrique, Lutts S. Seed priming of Trifolium repens L. improved germination and early seedling growth on heavy metal-contaminated soil. Water Air Soil Poll. 2001;225(4):1905. https://doi.org/ 10.1007/s11270-014-1905-1

37. Shao CX, Hu J, Song WJ, Hu WM. Effects of seed priming with chitosan solutions of different acidity on seed germination and physiological characteristics of maize seedling. J Zhejiang Univ (Agric and Life Sci). 2005;31:705-08.

38. Su J, Hirji R, Zhang L, He C, Selvaraj G, Wu R. Evaluation of the stress-inducible production of choline oxidase in transgenic rice as a strategy for producing the stress-protectant glycine betaine. J Exp Bot. 2006;57:1129-35. 10.1093/jxb/erj133

39. Foti R, Aburenia K, Tigerea A, GotosabJ, Gerec J. The efficacy of different seed priming osmotica on the establishment of maize (Zea mays L.) caryopses. J Arid Environ. 2008;72:1127-30. https://doi.org/10.1016/j.jaridenv.2007.11.008

40. Hasanuzzaman M, Hossain MA, Fujita M. Selenium in higher plants: physiological role, antioxidant metabolism and abiotic stress tolerance. J Plant Sci. 2010;5:354-75. https://doi.org/ 10.3923/jps.2010.354.375

41. Demir I, Ozuaydın I, Yasar F, Staden JV. Effect of smoke derived butenolide priming treatment on pepper and salvia seeds in relation to transplant quality and catalase activity. South Afr J Bot. 2012;78:83-87. https://doi.org/10.1016/ j.sajb.2011.05.009

42. Selem EE, Naguib DM. Alleviation of zinc toxicity in germinated wheat grains (Triticum aestivum L.) by seed priming with defensing like protein. Egypt J Bot. 2018; 59(3):591-03. https://doi.org/10.21608/ejbo.2018.3837.1179

43. Cao YY, Qi CD, Li S, Wang Z, Wang X, Wang J, Ren S, Li X, Zhang $\mathrm{Na}$, Guo YD. Melatonin alleviates copper toxicity via improving copper sequestration and ROS scavenging in cucumber. Plant Cell Physiol. 2019;60(3):562-74. https://doi.org/10.1093/pcp/ pcy226.

44. Nouairi I, Jalali K, Zribi F, Barhoumi F, Zribi K, and Mhadhbi H. Seed priming with calcium chloride improves the photosynthesis performance of faba bean plants subjected to cadmium stress. Photosynth. 2019;57(2):438-45. https://doi.org/10.32615/ ps.2019.055

45. Siddiqui MH, Al-Whaibi MH, Sakran AM. Calcium induced amelioration of boron toxicity in radish. J Plant Growth Regul. 2013;32:61-71. https://doi.org/10.1007/s00344-012-9276-6

46. Saidi I, Chtourou Y, Djebali W. Selenium alleviates cadmium toxicity by preventing oxidative stress in sunflower ( $\mathrm{He}$ lianthus annuus) seedlings. J Plant Physiol. 2014;171(5):85-91. https://doi.org/10.1016/j.jplph.2013.09.024

47. Gao M, Zhou J, Liu H, Zhang W, Hu Y, Liang J, Zhou J. Foliar spraying with silicon and selenium reduces cadmium uptake and mitigates cadmium toxicity in rice. Sci Total Environ. 2018, 631:1100-08. https://doi.org/10.1016/j.scitotenv.2018.03.047

48. Pereira AS, Dorneles AOS, Bernardy K, Sasso VM, Bernardy D, Possebom G, Rossato LV, Dressler VL, Tabaldi LA. Selenium and silicon reduce cadmium uptake and mitigate cadmium toxicity in Pfaffia glomerata (Spreng.) Pedersen plants by activation antioxidant enzyme system. Environ Sci Pollut Res. 2018;25:18548-58. https://doi.org/10.1007/s11356-018-2005-3

49. Rizwan M, Meunier JD, Miche H, Keller C. Effect of silicon on reducing cadmium toxicity in durum wheat (Triticum turgidum L. cv. Claudio W.) grown in a soil with aged contamina tion. J Hazard Mater. 2012;209:326-34. https://doi.org/ 10.1016/j.jhazmat.2012.01.033

50. Geng A, Wang X, Wu L, Wang F, Wu Z, Yang H, Chen Y, Wen D, Liu X. Silicon improves growth and alleviates oxidative stress in rice seedlings (Oryza sativa L.) by strengthening antioxidant defense and enhancing protein metabolism under arsanilic acid exposure. Ecotoxicol Environ Saf. 2018;158:266-73. https://doi.org/10.1016/j.ecoenv.2018.03.050

51. Jan S, Alyemeni MN, Wijaya L, Alam P, Siddique KH, Ahmad P. Interactive effect of 24-epibrassinolide and silicon alleviates cadmium stress via the modulation of antioxidant defense and glyoxalase systems and macronutrient content in Pisum sativum L. seedlings. BMC Plant Biol 2018;18:146. https://doi.org/ 10.1186/s12870-018-1359- 5

52. Shi Z, Yang S, Han D, Zhou Z, Li X, Liu Y, Zhang B. Silicon alleviates cadmium toxicity in wheat seedlings (Triticum aestivum L.) by reducing cadmium ion uptake and enhancing antioxidative capacity. Environ Sci Pollut Res. 2018;25:7638-46. https:// doi.org/10.1007/s11356-017-1077-9

53. Callan NW, Mathre DE, Miller JB. Bio-priming seed treatment for biological control of Pythium ultimum pre-emergence 
damping off in SH2 Sweet Corn. Plant Dis. 1990;74:368-72. https://scholarworks.montana.edu/xmlui/handle/1/3067

54. Bennett AJ, Whipps JM. Dual application of beneficial microorganisms to seed during drum priming. Appl Soil Ecol. 2008;38:83-89. https://doi.org/10.1016/j.apsoil.2007.08.001

55. Mishra J, Singh R, Arora NK. Alleviation of heavy metal stress in plants and remediation of soil by rhizosphere microorganisms. Front Microbiol. 2017;8:1706. https://doi.org/10.3389/ fmicb.2017.01706

56. Abou-Aly Hamed E, Youssef AM, Rasha M El-Meihy, Tawfika Taha A, El-Akshara Eman A. Evaluation of heavy metals tolerant bacterial strains as antioxidant agents and plant growth promoters. Biocat Agric Biotech. 2019;19:101-10. https:/ doi.org/10.1016/j.bcab.2019.101110

57. El-Meihy RM, Abou-Aly HE, Youssef AM., Tewfike TA, El-Alkshar EA. Efficiency of heavy metals-tolerant plant growth promoting bacteria for alleviating heavy metals toxicity on Sorghum. Environ Exp Bot. 2019; 162:295-301. https://doi.org/ 10.1016/j.envexpbot.2019.03.005

58. Chen YP, Li R, He JM. Magnetic field can alleviate toxicological effect induced by cadmium in mungbean seedlings. Ecotoxicology. 2011;20:760-69. https://doi.org/10.1007/s10646-011-0620-6
59. Anand A, Kumari A, Thakur M, Koul A. Hydrogen peroxide signaling integrates with phytohormones during the germination of magnetoprimed tomato seeds. Scientific Rep. 2019;9:8814. https://doi.org/10.1038/s41598-019-45102-5

60. Singh J, Lee BK. Influence of nano- $\mathrm{TiO}_{2}$ particles on the bioaccumulation of $\mathrm{Cd}$ in soybean plants (Glycine max): a possible mechanism for the removal of Cd from the contaminated soil. J Environ Manag. 2016;170:88-96. https://doi.org/10.1016/j. jenvman.2016.01.015

61. Li Z, Huang J. Effects of nanoparticle hydroxyapatite on growth and antioxidant system in pakchoi (Brassica chinensis L.) from cadmium-contaminated soil. J Nanomater. 2014; Article ID 470962. https://doi.org/10.1155/2014/470962

62. Tripathi DK, Singh S, Singh VP, Prasad SM, Chauhan DK, Dubey NK. Silicon nanoparticles more efficiently alleviate arsenate toxicity than silicon in maize cultivar and hybrid differing in arsenate tolerance. Front Environ Sci. 2016;4:46. https:// doi.org/10.3389/fenvs.2016.00046

63. Mahakham W, Sarmah AK, Maensiri S, Theerakulpisut P. Nanopriming technology for enhancing germination and starch metabolism of aged rice seeds using photosynthesized silver nanoparticles. Sci Rep. 2017;7:8263. https://doi.org/10.1038/ s41598-017-08669-5 